\title{
Using the Sub-Game Perfect Nash Equilibrium to Deduce the Effect of Government Subsidy on Consumption Rates and Prices
}

\author{
Dr. Magdi Amer \\ Department of Electrical Engineering \\ Faculty of Engineering, Fayoum University \\ Fayoum, Egypt
}

\author{
Dr. Ahmed Kattan \\ Department of Computer Science \\ Faculty of Computer and IS, Umm Al-Qura University \\ Makkah, Saudi Arabia
}

\begin{abstract}
Governments are interested in inducing positive habits and behaviors in its citizens and discouraging ones that are harmful to the individual or to the society. Taxation and legislation are usually used to discourage negative behaviors. Subsidy seems the politically correct way to encourage positive behaviors. In this paper, the Subgame Perfect Nash Equilibrium is used to deduce the effect of the government subsidy on the user consumption, prices and producer and distributor profits.
\end{abstract}

\section{Keywords—game-theory; subsidy}

\section{INTRODUCTION}

Governments all over the world have been trying to use taxation and subsidies to modify the behavior of its citizens, providing them with incentives to pursue actions that will benefit the society and discouraging them from those actions that are harmful to the individual and the society.

To fight smoking, governments had to go up against smoking companies in order to acquire the public approval needed to implement policies discouraging smoking as described in McKenzie [1]. The publicity war was won to the level that even heavy smokers were supportive for policies aiming to prevent youth from smoking, as proven in Lazuras [2]. Naiman [3] has proved that a full smoking ban was also associated in a decrease in the number of smokers and on secondhand smoke exposure in private settings.

Governments have also tried to solve traffic congestion by applying a congestion pricing on high-traffic roads. Small [4] and Ze-bin [5] have studied the effect of applying a congestion pricing on roads, both of which have shown, along with actual experience, that congestion-pricing car affects citizens' behavior and reduce traffic congestion. This was achieved as a congestion pricing encourages people commuting in a noncongested time, using non-congested roads and changing their transportation manners to use carpooling and public transportations [4]. The challenge was to acquire the political approval for such a system, as the citizens need to feel that it is just another added tax. Nevertheless, people gaining middle and lower incomes do not benefit from such a system, and when the saved time by the policy is not obvious, the highincome group and businesses do not benefit either [5].

Obesity and chronic diseases associated with poor dietary choices have become the leading cause of death [6]. When it comes to dissuade un-healthy eating habits, taxes or imposing higher service prices on over-weight citizens (fat-taxes) does not seem a valid alternative due to the high political opposition that such laws may generate and governments need to start to gather support for fat-taxes to make such policies acceptable by the voters [7]. Imposing taxes on unhealthy food is also unfair as they are imposed on both thin and fat citizens and are usually ineffective, as wealthy consumers are not affected by food prices while consumers with low incomes have the tendency to buy cheap energy-dense food [8].

There have been some attempts to impose taxes on unhealthy foods, but, in some cases, the government had to abandon such attempts due to the public opposition [9]. On the other hand, governments' attempts to encourage healthy eating habits through subsidies and incentives seem to be the politically correct choice. Such approaches are costly, as the cost of a statistical life saved has been estimated to be 1.29 million \$ in the USA [9].

In our research, we study the government incentives effect to increase healthy eating habits. Our work is based on Stackelberg [10], who has built a model in 1934 for the market behavior when there is a leader firm. Chen [11] and Simaan [12] have built the mathematical model for Stackelberg problems in the field of game theory. Shubik [13] has written a review on the application of game theory in economics. De Fraja [14] has established the mathematical framework for the research in mixed oligopoly market inspired from a survey of research in this area.

A mixed oligopoly market is a market where public and private firms compete where private firms aim to maximize their profit and public firms are interested in optimizing social targets [15]. Pal [16] has studied the effect of privatization in a mixed oligopoly with private, public and foreign firms when the government maximizes welfare through subsidy or through imposing tariffs on the foreign firms. He obtained interesting results such as privatization always improves welfare when using subsidies and it improves welfare when using tariffs if there are more than one public and one private company in the market and $\mathrm{k}$ is large, where $\mathrm{k}$ is the constant of the cost function $\mathrm{c}(\mathrm{q})=\mathrm{k} \mathrm{q} 2$, and $\mathrm{q}$ is the production level. In all cases, privatization when using subsidies decreases the consumption and increases prices. Welfare is defined as the profits of local companies, public and private, plus the amount of market 
surplus minus the actual subsidy paid by the government plus the tariff revenue. Pal [16] has also proven that subsidy increases welfare more than tariff regardless of the privatization if and only if $\mathrm{k}$ is small. Poyago-Theotoky [17] has studied the effect of subsidy on the production levels of companies in a mixed oligopoly. He has proven that the optimal subsidy that maximize welfare is the same whether all companies, including the public company, act as a profit maximizers or the public company act as a Stackelberg leader or the public company moves simultaneously with the other companies. Q. Gu [18] has studied the effect of subsidy for home-appliance replacement on the price of appliance.

\section{BUILBING THE MATHEMATICAL MODEL}

The goal of our research is to provide the Saudi government with a plan to manage the governmental product subsidy to increase the consumption of more healthy food. To model the market, we assume that there is a clear leader of the market for every subsidized product, as defined by Stackelberg [10]. We also assume that the production cost and the distribution cost are fixed, independent on the consumption levels and external parameters. We also assume that all players are competing in a free market and their goal is to maximize their profits. We also assume that all the producers and all the retailers form a cartel, thus behave like a single producer and a single retailer, as proven by Sertel [19].

In this research, the government is not interested in increasing welfare function, defined as the profit of local companies, public and private, plus the amount of market surplus plus the revenue that the government may gain from tariff and taxes minus any expenses the government pays such as subsidies. Instead, the government is only interested in increasing consumption, similar to the approach taken by Merrill [15]. This makes sense as the increase in the consumption of healthy food would reflect on the general health of the citizen, which benefits surpluses any short-term financial gain that the government would have obtain from maximizing the welfare function.

In this paper, we are going to discuss the effect of a product subsidy to the producer and the distributor or to the consumer both in case of free market and in a price-controlled market.

\section{A. The Market Without a Government Subsidy}

Let us first examine the market before any government intervention. Let us assume that the producer's unit sale price is $\mathrm{P}_{1 \mathrm{p}}$ and the unit sale of the retailer is $\mathrm{P}_{1 \mathrm{r}}$. Let us also assume that the production cost of a unit product is $\mathrm{C}_{\mathrm{p}}$ and the retailer operation cost of carrying a unit product is $\mathrm{C}_{\mathrm{r}}$.

Let us also assume that the demand for a product is a decreasing function of the sale price of the unit product, represented by $D_{1} \cdot D_{1}=K-\alpha P_{1 r}$, where $K$ is a positive parameter representing the market demand the product while $\alpha$ is a positive parameter representing the sensitivity coefficient of the end-customer for the retail price of the product unit.

The profit of the producer is $\Pi_{1 \mathrm{p}}=\left(\mathrm{P}_{1 \mathrm{p}}-\mathrm{Cp}\right)\left(\mathrm{K}-\alpha \mathrm{P}_{1 \mathrm{r}}\right)$

The profit of the retailer is $\Pi_{1 \mathrm{r}}=\left(\mathrm{P}_{1 \mathrm{r}}-\mathrm{Cr}-\mathrm{P}_{1 \mathrm{p}}\right)\left(\mathrm{K}-\alpha \mathrm{P}_{1 \mathrm{r}}\right)$
Using the assumption that the producer has enough market power to act as the market leader, we apply the Sub-game Perfect Nash Equilibrium (SPNE) [20 and 21] to calculate the retailer maximum profit given the sale price of the producer. This is given by differentiating $\Pi 1 \mathrm{r}$ with respect to $\mathrm{P} 1 \mathrm{r}$ and setting it to zero for maximization.

$$
\partial \Pi_{1 \mathrm{r}} / \partial \mathrm{P}_{1 \mathrm{r}}=\mathrm{K}-2 \alpha \mathrm{P}_{1 \mathrm{r}}+\alpha \mathrm{C}_{\mathrm{r}}+\alpha \mathrm{P}_{1 \mathrm{p}}=0
$$

$\mathrm{P}_{1 \mathrm{r}}=\left(\mathrm{K}+\alpha \mathrm{C}_{\mathrm{r}}+\alpha \mathrm{P}_{1 \mathrm{p}}\right) / 2 \alpha$, which represents the best response function of the retailer in response to the price of the market leader, the producer.

Given the best response function of the retailer, the output that maximizes the producer's profit is found by differentiating $\Pi_{1 \mathrm{p}}$ with respect to $\mathrm{P}_{1 \mathrm{p}}$ and setting it to zero.

$$
\begin{aligned}
& \partial \Pi_{1 \mathrm{r}} / \partial \mathrm{P}_{1 \mathrm{r}} \\
& \quad=\partial / \partial \mathrm{P}_{1 \mathrm{r}}\left[\left(\mathrm{P}_{1 \mathrm{p}}-\mathrm{C}_{\mathrm{p}}\right)\left(\mathrm{K}-\alpha\left[\left(\mathrm{K}+\alpha \mathrm{C}_{\mathrm{r}}+\alpha \mathrm{P}_{1 \mathrm{p}}\right) / 2 \alpha\right]\right)\right] \\
& \quad=0
\end{aligned}
$$

This results is $\mathrm{P}_{1 \mathrm{p}}=\left(\mathrm{K}+\alpha \mathrm{C}_{\mathrm{p}}-\alpha \mathrm{C}_{\mathrm{r}}\right) / 2 \alpha$.

Consequently, $\mathrm{P}_{1 \mathrm{r}}=\left(3 \mathrm{~K}+\alpha \mathrm{C}_{\mathrm{p}}+\alpha \mathrm{C}_{\mathrm{r}}\right) / 4 \alpha$.

The consumption in this case is $\mathrm{D}_{1}$

$$
\begin{aligned}
& =\left(\mathrm{K}-\alpha\left[\left(3 \mathrm{~K}+\alpha \mathrm{C}_{\mathrm{p}}+\alpha \mathrm{C}_{\mathrm{r}}\right) / 4 \alpha\right]\right) \\
& =1 / 4 \mathrm{~K}-1 / 4 \alpha\left(\mathrm{C}_{\mathrm{p}}+\mathrm{C}_{\mathrm{r}}\right)
\end{aligned}
$$

The maximum profit of the producer and the retailer will be

$$
\begin{aligned}
& \Pi_{1 \mathrm{p} \max }=\left(\mathrm{P}_{1 \mathrm{p} \max }-\mathrm{Cp}\right)\left(\mathrm{K}-\alpha \mathrm{P}_{1 \mathrm{r} \max }\right) \\
&= {\left[\mathrm{K}-\alpha\left(\mathrm{C}_{\mathrm{p}}+\mathrm{C}_{\mathrm{r}}\right)\right]^{2} / 8 \alpha } \\
& \Pi_{1 \mathrm{r} \max }=\left(\mathrm{P}_{1 \mathrm{r} \max }-\mathrm{Cr}-\mathrm{P}_{1 \mathrm{p} \max }\right)\left(\mathrm{K}-\alpha \mathrm{P}_{1 \mathrm{r} \max }\right) \\
&=\left[\mathrm{K}-\alpha\left(\mathrm{C}_{\mathrm{p}}+\mathrm{C}_{\mathrm{r}}\right)\right]^{2} / 16 \alpha
\end{aligned}
$$

The previous calculation allowed us to express the price of the producer and the retailer that maximize their profits, the consumption and the maximum profit of the producer and of the retailer as a function of the market demand for the product and the sensitivity of the end-customer consumption to the retail price of the product without any governmental intervention.

To simplify the calculations, let's assume that K'

$$
\begin{aligned}
& =\mathrm{K}-\alpha\left(\mathrm{C}_{\mathrm{p}}+\mathrm{C}_{\mathrm{r}}\right) \\
& \Pi_{1 \mathrm{p} \max }=\left[\mathrm{K}^{\prime}\right]^{2} / 8 \alpha \\
& \Pi_{1 \mathrm{r} \max }=\left[\mathrm{K}^{\prime}\right]^{2} / 16 \alpha
\end{aligned}
$$

\section{B. The Market in Case of a Government Subsidy to the Producer and Retailer}

Now, let us assume that in order to encourage the increase of a product consumption, the government decides to subsidies the producer and the retailer of this product with $\beta \mathrm{p}$ and $\beta \mathrm{r}$ respectively.

Thus, the profit of the producer becomes $\Pi_{2 \mathrm{p}}=$ $\left(\mathrm{P}_{2 \mathrm{p}}-\left(\mathrm{C}_{\mathrm{p}}-\beta_{\mathrm{p}}\right)\right)\left(\mathrm{K}-\alpha \mathrm{P}_{2 \mathrm{r}}\right)$. 
The profit of the retailer becomes $\Pi_{2 \mathrm{r}}=$ $\left(\mathrm{P}_{2 \mathrm{r}}-\left(\mathrm{C}_{\mathrm{r}}-\beta_{\mathrm{r}}\right)-\mathrm{P}_{2 \mathrm{p}}\right)\left(\mathrm{K}-\alpha \mathrm{P}_{2 \mathrm{r}}\right)$.

Similar to the previous calculations, the prices of the producer and the retailer that maximize their profits when the producer is the effective market leader are:

$$
\begin{aligned}
\mathrm{P}_{2 \mathrm{p}} & =\left(\mathrm{K}+\alpha\left(\mathrm{C}_{\mathrm{p}}-\beta_{\mathrm{p}}\right)-\alpha\left(\mathrm{C}_{\mathrm{r}}-\beta_{\mathrm{r}}\right)\right) / 2 \alpha \\
& =1 / 2 \mathrm{k} / \alpha+1 / 2\left(\mathrm{C}_{\mathrm{p}}-\mathrm{C}_{\mathrm{r}}\right)-1 / 2\left(\beta_{\mathrm{p}}-\beta_{\mathrm{r}}\right) \\
& =\mathrm{P}_{1 \mathrm{p}}+1 / 2 \beta_{\mathrm{r}}-1 / 2 \beta_{\mathrm{p}} \\
\mathrm{P}_{2 \mathrm{r}} & =\left(3 \mathrm{~K}+\alpha\left(\mathrm{C}_{\mathrm{p}}-\beta_{\mathrm{p}}\right)+\alpha\left(\mathrm{C}_{\mathrm{r}}-\beta_{\mathrm{r}}\right)\right) / 4 \alpha \\
& =3 / 4 \mathrm{k} / \alpha+1 / 4\left(\mathrm{C}_{\mathrm{p}}+\mathrm{C}_{\mathrm{r}}\right)-1 / 4\left(\beta_{\mathrm{p}}+\beta_{\mathrm{r}}\right) \\
& =\mathrm{P}_{1 \mathrm{r}}-1 / 4\left(\beta_{\mathrm{p}}+\beta_{\mathrm{r}}\right)
\end{aligned}
$$

The consumption in this case is

$$
\begin{aligned}
D_{2} & =\left(K-\alpha\left[3 / 4 \mathrm{k} / \alpha+1 / 4\left(C_{p}+C_{r}\right)-1 / 4\left(\beta_{p}+\beta_{r}\right)\right]\right) \\
& =1 / 4 K-1 / 4 \alpha\left(C_{p}+C_{r}\right)+1 / 4 \alpha\left(\beta_{p}+\beta_{r}\right)
\end{aligned}
$$

Knowing that the consumption that maximize the profit of the producer and retailer without government subsidy is $\mathrm{D}_{1}=$ $1 / 4 \mathrm{~K}-1 / 4 \alpha\left(\mathrm{C}_{\mathrm{p}}+\mathrm{C}_{\mathrm{r}}\right)$

$\mathrm{D}_{2}=\mathrm{D}_{1}+1 / 4 \alpha\left(\beta_{\mathrm{p}}+\beta_{\mathrm{r}}\right)$

The maximum profit of the producer and the retailer are:

$$
\begin{aligned}
& \Pi_{2 \mathrm{p} \max }=\left[\mathrm{K}-\alpha\left(\mathrm{C}_{\mathrm{p}}+\mathrm{C}_{\mathrm{r}}\right)+\alpha\left(\beta_{\mathrm{p}}+\beta_{\mathrm{r}}\right)\right]^{2} / 8 \alpha \\
& \Pi_{2 \mathrm{r} \max }=\left[\mathrm{K}-\alpha\left(\mathrm{C}_{\mathrm{p}}+\mathrm{C}_{\mathrm{r}}\right)+\alpha\left(\beta_{\mathrm{p}}+\beta_{\mathrm{r}}\right)\right]^{2} / 16 \alpha \\
& \text { Using } \mathrm{K}^{\prime}=\mathrm{K}-\alpha\left(\mathrm{C}_{\mathrm{p}}+\mathrm{C}_{\mathrm{r}}\right) \\
& \begin{aligned}
\Pi_{2 \mathrm{p} \max } & =\left[\mathrm{K}^{\prime}+\alpha\left(\beta_{\mathrm{p}}+\beta_{\mathrm{r}}\right)\right]^{2} / 8 \alpha \\
& =\left[\left(\mathrm{K}^{\prime}\right)^{2}+2 \alpha\left(\beta_{\mathrm{p}}+\beta_{\mathrm{r}}\right) \mathrm{K}^{\prime}+\alpha^{2}\left(\beta_{\mathrm{p}}+\beta_{\mathrm{r}}\right)^{2}\right] / 8 \alpha \\
& =\Pi_{1 \mathrm{p} \max }+1 / 4\left(\beta_{\mathrm{p}}+\beta_{\mathrm{r}}\right) \mathrm{K}^{\prime}+1 / 8 \alpha\left(\beta_{\mathrm{p}}+\beta_{\mathrm{r}}\right)^{2} \\
\Pi_{2 \mathrm{r} \max } & =\Pi_{1 \mathrm{p} \max }+1 / 8\left(\beta_{\mathrm{p}}+\beta_{\mathrm{r}}\right) \mathrm{K}^{\prime}+\left(\alpha\left(\beta_{\mathrm{p}}+\beta_{\mathrm{r}}\right)^{2}\right) / 16
\end{aligned}
\end{aligned}
$$

C. The Market in Case of a Government Subsidy to the Consumer

Let us assume that the government decides to subsidies the consumer with an amount $\beta_{\mathrm{c}}$ for every product unit.

Thus, the profit of the producer becomes $\Pi_{3 p}=$

$\left(\mathrm{P}_{3 \mathrm{p}}-\mathrm{C}_{\mathrm{p}}\right)\left(\mathrm{K}-\alpha\left(\mathrm{P}_{3 \mathrm{r}}-\beta_{\mathrm{c}}\right)\right)$.

The profit of the retailer becomes $\Pi_{3 \mathrm{r}}$

$=\left(\mathrm{P}_{3 \mathrm{r}}-\mathrm{C}_{\mathrm{r}}-\mathrm{P}_{3 \mathrm{p}}\right)\left(\mathrm{K}-\alpha\left(\mathrm{P}_{3 \mathrm{r}}-\beta_{\mathrm{c}}\right)\right)$.

The prices of the producer and the retailer that maximize their profits are:

$$
\begin{aligned}
\mathrm{P}_{3 \mathrm{p}} & =\left(\mathrm{K}+\alpha \beta_{\mathrm{c}}+\alpha \mathrm{C}_{\mathrm{p}}-\alpha \mathrm{C}_{\mathrm{r}}\right) / 2 \alpha \\
& =1 / 2 \mathrm{k} / \alpha+1 / 2\left(\mathrm{C}_{\mathrm{p}}-\mathrm{C}_{\mathrm{r}}\right)+1 / 2 \beta_{\mathrm{c}} \\
\mathrm{P}_{3 \mathrm{r}} & =\left(3 \mathrm{~K}+3 \alpha \beta_{\mathrm{c}}+\alpha \mathrm{C}_{\mathrm{p}}+\alpha \mathrm{C}_{\mathrm{r}}\right) / 4 \alpha \\
& =3 / 4 \mathrm{k} / \alpha+1 / 4\left(\mathrm{C}_{\mathrm{p}}+\mathrm{C}_{\mathrm{r}}\right)+3 / 4 \beta_{\mathrm{c}}
\end{aligned}
$$

The consumption in this case is

$$
\mathrm{D}_{3}=\left(\mathrm{K}-\alpha\left(\left[3 / 4 \mathrm{k} / \alpha+1 / 4\left(\mathrm{C}_{\mathrm{p}}+\mathrm{C}_{\mathrm{r}}\right)+3 / 4 \beta_{\mathrm{c}}\right]-\beta_{\mathrm{c}}\right)\right)
$$

$$
=1 / 4 \mathrm{~K}-1 / 4 \alpha\left(\mathrm{C}_{\mathrm{p}}+\mathrm{C}_{\mathrm{r}}\right)+1 / 4 \alpha \beta_{\mathrm{c}}
$$

Knowing that $\mathrm{D}_{1}=1 / 4 \mathrm{~K}-1 / 4 \alpha\left(\mathrm{C}_{\mathrm{p}}+\mathrm{C}_{\mathrm{r}}\right)$

$\mathrm{D}_{3}=\mathrm{D}_{1}+1 / 4 \alpha \beta_{\mathrm{c}}$

The profit of the producer and the retailer are:

$$
\begin{aligned}
\Pi_{3 \mathrm{p} \max }= & \left(\mathrm{P}_{3 \mathrm{p} \max }-\mathrm{C}_{\mathrm{p}}\right)\left(\mathrm{K}-\alpha\left(\mathrm{P}_{3 \mathrm{r} \max }+\beta_{\mathrm{c}}\right)\right) \\
& =\left[\mathrm{K}+\alpha \beta_{\mathrm{c}}-\alpha\left(\mathrm{C}_{\mathrm{p}}+\mathrm{C}_{\mathrm{r}}\right)\right]^{2} / 8 \alpha \\
\Pi_{3 \mathrm{r} \max } & =\left(\mathrm{P}_{3 \mathrm{r} \max }-{ }_{\mathrm{Cr}}-\mathrm{P}_{3 \mathrm{p} \max }\right)\left(\mathrm{K}-\alpha \mathrm{P}_{3 \mathrm{r} \max }\right) \\
& =\left[\mathrm{K}+\alpha \beta_{\mathrm{c}}-\alpha\left(\mathrm{C}_{\mathrm{p}}+\mathrm{C}_{\mathrm{r}}\right)\right]^{2} / 16 \alpha
\end{aligned}
$$

Using $\mathrm{K}^{\prime}=\mathrm{K}-\alpha\left(\mathrm{C}_{\mathrm{p}}+\mathrm{C}_{\mathrm{r}}\right)$

$$
\Pi_{3 \mathrm{p} \max }=\left[\mathrm{K}^{\prime}+\alpha \beta_{\mathrm{c}}\right]^{2} / 8 \alpha=\Pi_{1 \mathrm{p} \max }+1 / 4 \beta_{\mathrm{c}} \mathrm{K}^{\prime}+1 / 8 \alpha \beta_{\mathrm{c}}{ }^{2}
$$

$\Pi_{3 \mathrm{r} \max }=\left[\mathrm{K}^{\prime}+\alpha \beta_{\mathrm{c}}\right]^{2} / 16 \alpha=\Pi_{1 \mathrm{p} \max }+1 / 8 \beta_{\mathrm{c}} \mathrm{K}^{\prime}+\left(\alpha \beta_{\mathrm{c}}{ }^{2}\right) / 16$

Comparing the results of product consumption in case of producer and retailer subsidies and in the case of consumer subsidy, we find that if the sum of the subsidy per product unit given to the retailer and the producer is the same as subsidy per product unit given to the consumer (i.e. if $\beta_{c}=\beta_{p}+\beta_{r}$ ), the increase in the product consumption is the same and the profit of the producer and the retailer is the same. Moreover, it does not matter how the government divides the profit between the retailer and producer, their profit are the same. This is an expected result due to the fact that it is the producer that is driving the market and controlling the profits.

\section{The Market in Case of a Government Subsidy to Illegible Citizen}

Assume that the government decides to subsidies only a percentage $\varepsilon$ of the total citizens by $\beta_{\mathrm{c}}$ for every product unit. be:

In this case the consumption for un-subsidized citizen will

$\mathrm{D}_{4 \mathrm{a}}=\mathrm{K}-\alpha \mathrm{P}_{4 \mathrm{r}}$

The consumption for subsidized citizen will be:

$\mathrm{D}_{4 \mathrm{~b}}=\mathrm{K}-\alpha\left(\mathrm{P}_{4 \mathrm{r}}-\beta_{\mathrm{c}}\right)$

So the average consumption will be:

$$
\begin{aligned}
\mathrm{D}_{4} & =(1-\varepsilon) \mathrm{D}_{4 \mathrm{a}}+\varepsilon \mathrm{D}_{4 \mathrm{~b}} \\
& =\mathrm{K}-\alpha \mathrm{P}_{4 \mathrm{r}}+\varepsilon \alpha \beta_{\mathrm{c}}
\end{aligned}
$$

The profit of the producer becomes $\Pi_{4 \mathrm{p}}$

$$
=\left(\mathrm{P}_{3 \mathrm{p}}-\mathrm{C}_{\mathrm{p}}\right)\left(\mathrm{K}-\alpha \mathrm{P}_{4 \mathrm{r}}+\varepsilon \alpha \beta_{\mathrm{c}}\right)
$$

The profit of the retailer becomes $\Pi_{4 \mathrm{r}}$ $=\left(\mathrm{P}_{3 \mathrm{r}}-\mathrm{Cr}-\mathrm{P}_{3 \mathrm{p}}\right)\left(\mathrm{K}-\alpha \mathrm{P}_{4 \mathrm{r}}+\varepsilon \alpha \beta_{\mathrm{c}}\right)$

Using SPNE, the price of the producer and the retailer that will maximize their profit is:

$\mathrm{P}_{4 \mathrm{p}}=1 / 2 \mathrm{k} / \alpha+1 / 2\left(\mathrm{C}_{\mathrm{p}}-\mathrm{C}_{\mathrm{r}}\right)+1 / 2 \varepsilon \beta_{\mathrm{c}}=\mathrm{P}_{1 \mathrm{p}}+1 / 2 \varepsilon \beta_{\mathrm{c}}$

$\mathrm{P}_{4 \mathrm{r}}=3 / 4 \mathrm{k} / \alpha+1 / 4\left(\mathrm{C}_{\mathrm{p}}+\mathrm{C}_{\mathrm{r}}\right)+3 / 4 \varepsilon \beta_{\mathrm{c}}=\mathrm{P}_{1 \mathrm{r}}+3 / 4 \varepsilon \beta_{\mathrm{c}}$

The consumption in this case is:

$\mathrm{D}_{4}=\mathrm{K}-\alpha\left[3 / 4 \mathrm{k} / \alpha+1 / 4\left(\mathrm{C}_{\mathrm{p}}+\mathrm{C}_{\mathrm{r}}\right)+3 / 4 \varepsilon \beta_{\mathrm{c}}\right]+\varepsilon \alpha \beta_{\mathrm{c}}$ 
$=1 / 4 \mathrm{~K}-1 / 4 \alpha\left(\mathrm{C}_{\mathrm{p}}+\mathrm{C}_{\mathrm{r}}\right)+1 / 4 \varepsilon \alpha \beta_{\mathrm{c}}$

$=\mathrm{D}_{1}+1 / 4 \varepsilon \alpha \beta_{\mathrm{c}}$

The profit of the producer and the retailer are:

$$
\begin{aligned}
& \Pi_{4 \mathrm{p} \max }=\Pi_{1 \mathrm{p} \max }+1 / 4 \varepsilon \beta_{\mathrm{c}} \mathrm{K}^{\prime}+1 / 8 \alpha \varepsilon^{2} \beta_{\mathrm{c}}{ }^{2} \\
& \Pi_{4 \mathrm{r} \max }=\Pi_{1 \mathrm{p} \max }+1 / 8 \varepsilon \beta_{\mathrm{c}} \mathrm{K}^{\prime}+\left(\alpha \varepsilon^{2} \beta_{\mathrm{c}}{ }^{2}\right) / 16
\end{aligned}
$$

It is important to notice that when the government subsidies a product in a free market environment, it will be in the best interest of the producer and the retailer to increase their prices to maximize their profits when the subsidy is paid to the consumer, or to reduce their prices by only a percentage of the subsidy when it is paid directly to the producer and the retailer. As a result, the consumption will increase only by $1 / 4 \alpha \beta_{c}, 1 / 4 \varepsilon$ $\alpha \beta_{\mathrm{c}}$ or $1 / 4 \alpha\left(\beta_{\mathrm{p}}+\beta_{\mathrm{r}}\right)$ depending whether the subsidy is paid to all consumers, a sub-set of the consumers or to the producer and retailer. This means that only $25 \%$ of the government funding will actually be used to increase the consumption while the other $75 \%$ will be used to increase the profit of the producer and retailer.

\section{E. Government Subsidy to the Producer and Retailer under Price Control}

Let us consider the case where the government decides to provide product subsidy only if the producer and the retailer fix their prices during the subsidy period to be equal to their prices before the subsidy reduce by the amount of subsidy. In this case, the producer and retailer prices will be:

$\mathrm{P}_{5 \mathrm{p}}=\left(\left(\mathrm{K}+\alpha \mathrm{C}_{\mathrm{p}}-\alpha \mathrm{C}_{\mathrm{r}}\right) / 2 \alpha\right)-\beta_{\mathrm{p}}$

$\mathrm{P}_{5 \mathrm{r}}=\left(\left(3 \mathrm{~K}+\alpha \mathrm{C}_{\mathrm{p}}+\alpha \mathrm{C}_{\mathrm{r}}\right) / 4 \alpha\right)-\left(\beta_{\mathrm{p}}+\beta_{\mathrm{r}}\right)$

Note that the retailer sale price is reduced by both the subsidy of the retailer and the producer, as the later was used to reduce the price the retailer paid to the producer.

The consumption in this case will be:

$$
\mathrm{D}_{5}=\mathrm{K}-\alpha\left(\left(\left(3 \mathrm{~K}+\alpha \mathrm{C}_{\mathrm{p}}+\alpha \mathrm{C}_{\mathrm{r}}\right) / 4 \alpha\right)-\left(\beta_{\mathrm{p}}+\beta_{\mathrm{r}}\right)\right)
$$$$
=\mathrm{D}_{1}+\alpha\left(\beta_{\mathrm{p}}+\beta_{\mathrm{r}}\right)
$$

In this case the producer profit is:

$$
\begin{aligned}
& \Pi_{5 \mathrm{p}}=\left(\mathrm{P}_{5 \mathrm{p}}-\mathrm{C}_{\mathrm{p}}+\beta_{\mathrm{p}}\right)\left(\mathrm{D}_{5}\right) \\
& \quad=\left(\left(\left(\mathrm{K}+\alpha \mathrm{C}_{\mathrm{p}}-\alpha \mathrm{C}_{\mathrm{r}}\right) / 2 \alpha-\beta_{\mathrm{p}}\right)-\mathrm{Cp}+\beta \mathrm{p}\right)(1 / 4 \mathrm{~K}-1 / 4 \alpha \\
& (\mathrm{Cp}+\mathrm{Cr})+\alpha(\beta \mathrm{p}+\beta \mathrm{r}))
\end{aligned}
$$

Using the assumption $\mathrm{K}^{\prime}=\mathrm{K}-\alpha\left(\mathrm{C}_{\mathrm{p}}+\mathrm{C}_{\mathrm{r}}\right)$

$$
\begin{aligned}
\Pi_{5 \mathrm{p}} & =1 / 8\left(\mathrm{~K}^{\prime}\right)^{2} / \alpha+1 / 2 \mathrm{~K}^{\prime}\left(\beta_{\mathrm{p}}+\beta_{\mathrm{r}}\right) \\
& =\Pi_{1 \mathrm{p} \max }+1 / 2\left(\mathrm{~K}-\alpha\left(\mathrm{C}_{\mathrm{p}}+\mathrm{C}_{\mathrm{r}}\right)\right)\left(\beta_{\mathrm{p}}+\beta_{\mathrm{r}}\right)
\end{aligned}
$$

The retailer profit is:

$$
\begin{aligned}
& \Pi_{5 \mathrm{r}}=\left(\mathrm{P}_{5 \mathrm{r}}-\mathrm{C}_{\mathrm{r}}-\mathrm{P}_{5 \mathrm{p}}+\beta_{\mathrm{r}}\right)\left(\mathrm{D}_{5}\right) \\
& \quad=\left[\left(\left(3 \mathrm{~K}+\alpha \mathrm{C}_{\mathrm{p}}+\alpha \mathrm{C}_{\mathrm{r}}\right) / 4 \alpha\right)-\left(\beta_{\mathrm{p}}+\beta_{\mathrm{r}}\right)-\mathrm{C}_{\mathrm{r}}-\left[\left(\left(\mathrm{K}+\alpha \mathrm{C}_{\mathrm{p}}-\right.\right.\right.\right. \\
& \left.\left.\left.\left.\alpha \mathrm{C}_{\mathrm{r}}\right) / 2 \alpha\right)-\beta_{\mathrm{p}}\right]+\beta_{\mathrm{r}}\right] *\left(1 / 4 \mathrm{~K}-1 / 4 \alpha\left(\mathrm{C}_{\mathrm{p}}+\mathrm{C}_{\mathrm{r}}\right)+\alpha\left(\beta_{\mathrm{p}}+\beta_{\mathrm{r}}\right)\right)
\end{aligned}
$$

Using the assumption $\mathrm{K}^{\prime}=\mathrm{K}-\alpha\left(\mathrm{C}_{\mathrm{p}}+\mathrm{C}_{\mathrm{r}}\right)$

$$
\Pi_{5 \mathrm{r}}=\left(\mathrm{K}^{\prime}\right)^{2} /(16 \alpha)+1 / 4 \mathrm{~K}^{\prime}\left(\beta_{\mathrm{p}}+\beta_{\mathrm{r}}\right)
$$

$$
=\Pi_{1 r \max }+1 / 4\left(K-\alpha\left(C_{p}+C_{r}\right)\right)\left(\beta_{p}+\beta_{r}\right)
$$

\section{F. Government Subsidy to the Consumer under Price Control}

If the government decides to pass regulations that freeze the prices of the producer and retailer to what they were before the subsidy, and pay the subsidy directly to the consumer, the producer and retailer prices will be:

$\mathrm{P}_{6 \mathrm{p}}=\left(\left(\mathrm{K}+\alpha \mathrm{C}_{\mathrm{p}}-\alpha \mathrm{C}_{\mathrm{r}}\right) / 2 \alpha\right)$

$\mathrm{P}_{6 \mathrm{r}}=\left(\left(3 \mathrm{~K}+\alpha \mathrm{C}_{\mathrm{p}}+\alpha \mathrm{C}_{\mathrm{r}}\right) / 4 \alpha\right)$

The consumption in this case will be:

$\mathrm{D}_{6}=\mathrm{K}-\alpha\left(\left(\left(3 \mathrm{~K}+\alpha \mathrm{C}_{\mathrm{p}}+\alpha \mathrm{C}_{\mathrm{r}}\right) / 4 \alpha\right)-\left(\beta_{\mathrm{c}}\right)\right)$

$=\mathrm{D}_{1}+\alpha \beta_{\mathrm{c}}$

In this case the producer profit is:

$\Pi_{6 \mathrm{p}}=\left(\left(\left(\mathrm{K}+\alpha \mathrm{C}_{\mathrm{p}}-\alpha \mathrm{C}_{\mathrm{r}}\right) / 2 \alpha\right)-\mathrm{C}_{\mathrm{p}}\right)\left(1 / 4 \mathrm{~K}-1 / 4 \alpha\left(\mathrm{C}_{\mathrm{p}}+\mathrm{C}_{\mathrm{r}}\right)+\alpha\right.$ $\left.\beta_{\mathrm{c}}\right)$

Using the assumption $\mathrm{K}^{\prime}=\mathrm{K}-\alpha\left(\mathrm{C}_{\mathrm{p}}+\mathrm{C}_{\mathrm{r}}\right)$

$$
\begin{aligned}
\Pi_{6 \mathrm{p}} & =1 / 8\left(\mathrm{~K}^{\prime}\right)^{2} / \alpha+1 / 2 \mathrm{~K}^{\prime}\left(\beta_{\mathrm{c}}\right) \\
& =\Pi_{1 \mathrm{p} \max }+1 / 2\left(\mathrm{~K}-\alpha\left(\mathrm{C}_{\mathrm{p}}+\mathrm{C}_{\mathrm{r}}\right)\right)\left(\beta_{\mathrm{c}}\right)
\end{aligned}
$$

The retailer profit is:

$$
\begin{aligned}
\Pi_{6 \mathrm{r}} & =\left(\mathrm{P}_{6 \mathrm{r}}-\mathrm{C}_{\mathrm{r}}-\mathrm{P}_{6 \mathrm{p}}\right)\left(\mathrm{D}_{6}\right) \\
& =\left(\mathrm{K}^{\prime}\right)^{2} /(16 \alpha)+1 / 4 \mathrm{~K}^{\prime} \beta_{\mathrm{c}} \\
& =\Pi_{1 \mathrm{r} \max }+1 / 4\left(\mathrm{~K}-\alpha\left(\mathrm{C}_{\mathrm{p}}+\mathrm{C}_{\mathrm{r}}\right)\right)\left(\beta_{\mathrm{c}}\right)
\end{aligned}
$$

\section{G. Government Subsidy to Illegible Consumer under Price Control}

If the government decides to pass regulations that freeze the prices of the producer and retailer to what they were before the subsidy, and pay the subsidy to a percentage $\varepsilon$ of the consumers who are eligible to receive financial aid, the producer and retailer prices will be:

$\mathrm{P}_{7 \mathrm{p}}=\left(\left(\mathrm{K}+\alpha \mathrm{C}_{\mathrm{p}}-\alpha \mathrm{C}_{\mathrm{r}}\right) / 2 \alpha\right)$

$\mathrm{P}_{7 \mathrm{r}}=\left(\left(3 \mathrm{~K}+\alpha \mathrm{C}_{\mathrm{p}}+\alpha \mathrm{C}_{\mathrm{r}}\right) / 4 \alpha\right)$

The average consumption in this case will be:

$$
\begin{aligned}
\mathrm{D}_{7} & =\mathrm{K}-\alpha \mathrm{P}_{7 \mathrm{r}}+\varepsilon \alpha \beta_{\mathrm{c}} \\
& =\mathrm{K}-\alpha\left(\left(3 \mathrm{~K}+\alpha \mathrm{C}_{\mathrm{p}}+\alpha \mathrm{C}_{\mathrm{r}}\right) / 4 \alpha\right)+\varepsilon \alpha \beta_{\mathrm{c}} \\
& =\mathrm{D}_{1}+\varepsilon \alpha \beta_{\mathrm{c}}
\end{aligned}
$$

In this case the producer profit is:

$\Pi_{7 \mathrm{p}}=\left(\left(\left(\mathrm{K}+\alpha \mathrm{C}_{\mathrm{p}}-\alpha \mathrm{C}_{\mathrm{r}}\right) / 2 \alpha\right)-\mathrm{C}_{\mathrm{p}}\right)\left(1 / 4 \mathrm{~K}-1 / 4 \alpha\left(\mathrm{C}_{\mathrm{p}}+\mathrm{C}_{\mathrm{r}}\right)+\alpha\right.$ $\left.\varepsilon \beta_{\mathrm{c}}\right)$

Using the assumption $\mathrm{K}^{\prime}=\mathrm{K}-\alpha\left(\mathrm{C}_{\mathrm{p}}+\mathrm{C}_{\mathrm{r}}\right)$

$$
\begin{aligned}
\Pi_{7 \mathrm{p}} & =1 / 8\left(\mathrm{~K}^{\prime}\right)^{2} / \alpha+1 / 2 \mathrm{~K}^{\prime}\left(\varepsilon \beta_{\mathrm{c}}\right) \\
& =\Pi_{1 \mathrm{p} \max }+1 / 2\left(\mathrm{~K}-\alpha\left(\mathrm{C}_{\mathrm{p}}+\mathrm{C}_{\mathrm{r}}\right)\right)\left(\varepsilon \beta_{\mathrm{c}}\right)
\end{aligned}
$$

Using the assumption $\mathrm{K}^{\prime}=\mathrm{K}-\alpha\left(\mathrm{C}_{\mathrm{p}}+\mathrm{C}_{\mathrm{r}}\right)$, the retailer profit is:

$$
\Pi_{7 \mathrm{p}}=\Pi_{1 \mathrm{r} \max }+1 / 4\left(\mathrm{~K}-\alpha\left(\mathrm{C}_{\mathrm{p}}+\mathrm{C}_{\mathrm{r}}\right)\right)\left(\varepsilon \beta_{\mathrm{c}}\right)
$$




\section{CONCLUSION}

When a government wants to reduce bad habits of its citizens such as smoking, taxation seems the way to go. On the other hand, to increase positive behavior such as eating healthier food, taxation of those who do not follow this behavior is a very difficult choice [7, 8 and 9]. Subsidy seems a more politically correct approach.

In this paper, we applied the Stackelberg [10] model and the Sub-game Perfect Nash Equilibrium [20 and 21] to understand the effect of subsidy on product consumption. To simplify the calculations, we made a few assumptions that are realistic, such as the existence of a market leader as defined by Stackelberg for each subsidized product, that the production cost and the distribution cost are not affected by the production level and that the consumption is a linear function inversely proportional to the product sale price.

In a free market environment, no matter how the subsidy is paid, it will always be in the best interest of the producer and retailer to increase their prices to increase their profit. In fact, only $25 \%$ of the government-subsidized money will be used to increase the consumption, while the rest will go towards increasing the profit of the producer and the consumer.

On the other hand, if the government decides to freeze the product price of the producer and retailer to what they were before the start of the subsidy program, all the subsidized money will be used to decrease the sale price of the product. In this case, all the funds the government spends for product subsidy will go towards increasing the product consumption. The producer and retailer will still see an increase in their profit due to an increase in the consumption. It is in the best interest of the government to force a price freeze on subsidized product either through regulations or by playing the role of the actual market leader.

Another important finding was that it does not matter whether the government pays the subsidy to the citizens or to the producer and the retailer and it does not matter the percentage given to the retailer compared to the producer. In all cases, if there is a market leader as defined by Stackelberg [10], the consumption rate, the product sale price and the profit of the producer and the consumer will be the same for the same amount of subsidy per product unit. The government can choose the subsidy approach that is easier to manage and have the best marketing effect on the citizens.

\section{REFERENCES}

[1] R. B. McKenzie, "Smoking War", in Heavy!, Springer, pp. 149-161, 2012.

[2] L. Lazuras, A. Rodafinos, D. B. Panagiotakos, J. R. Thyrian, U. John, and E. Polychronopoulos, "Support for smoke-free policies in a prosmoking culture: findings from the European survey on tobacco control attitudes and knowledge", in International Journal of Public Health, Volume 54, Number 6, pp. 403-408, 2009.
[3] A. B. Naiman, R. H. Glazier, and R. Moineddin, "Is there an impact of public smoking bans on self-reported smoking status and exposure to secondhand smoke?", in BMC Public Health, Volume 11, Number 1, 2011. On Line: http://www.biomedcentral.com/1471-2458/11/146/

[4] K.A. Small, and J.A. Gomez-Ibanez, "Road pricing for congestion management: Transition from theory to policy", In: Road Prices, Traffic Congestion and the Environment, Issues of Efficiency and Social Feasibility, K Button, and E Verhoet (Eds), Edward Elgar Publishing, pp 213-246, 1998. On-line: http://www.uctc.net/papers/391.pdf

[5] Z. Ze-bin, A. Shi, and W. Jian, "The Welfare Effects of Congested Road-use Pricing and Redistribution Way", International Conference on Management Science and Engineering (ICMSE), pp: 2235 - 2240, 2007.

[6] J M. McGinnis, M. Nestle, "The Surgeon General's report on nutrition and health: policy implications and implementation strategies" , American journal of clinical nutrition, volume 49 (1) pp:23-28, 1989. On-line: http://ajcn.nutrition.org/content/49/1/23.full.pdf+html

[7] R. B. McKenzie, "Fat Taxes, Bans, and Discrimination", in Heavy!, Springer, pp: 163-200, 2012.

[8] M. J. Salois, J. R. Richard, "The Impacts of Fat Taxes and Thin Subsidies on Nutrient Intakes", Agricultural Economics Society, 85th Annual Conference, April 18-20, 2011, Warwick University, Coventry, UK. On-line: http://purl.umn.edu/108789

[9] S. Cash, D. Sunding, D. Zilberman, "Fat taxes and thin subsidies: prices, dietand Healthy outcomes", American Agricultural Economics Association, 2004 Annual meeting, August 1-4, Denver, CO On-line: http://purl.umn.edu/19961

[10] H. V. Stackelberg, "Market Structure and Equilibrium: 1st Edition Translation into English", Springer, 134 pages, 2011.

[11] C.I. Chen, and J. B. Jr Cruz, Stackelberg Solution for Two-Person Games with Biased Information Patterns, in IEEE Transactions on Automatic Control, VoI. AC-17, No. 5, 1972.

[12] M. Simaan, and Jr. J.B. Cruz, "On the Stackelberg Strategy in NonzeroSum Games", in Journal of Optimization Theory and Applications, Vol. 11, No. 5, pp. 533-555, May 1973. On-Line: http://link.springer.com/content/pdf/10.1007\%2FBF00935665

[13] M. Shubik, "Game theory models and methods in political economy", in Handbook of Mathematical Economics, Volume 1, Editors: K. J. Arrow, and M. D. Intriligator, Elsevier, pp 285-330, 1981.

[14] G. de Fraja, and F. Delbono, "Game theoretic models of mixed oligopoly", in Journal of Economic Surveys, Vol. 4, No. 1, pp: $1-17$, 1990.

[15] W. C. Merrill; N. Schneider, "Government Firms in Oligopoly Industries: A Short-Run Analysis" in the Quarterly Journal of Economics, Volume 80, Issue 3, Oxford Journals, pp: 400-412, 1966

[16] D. Pal, and M. D. White, "Mixed Oligopoly, Privatization and Strategic Trade Policy", in the southern economic journal, Volume 65, Issue 2, pp 264-281

[17] J. Poyago-Theotoky, "Mixed oligopoly, subsidization and the order of firms' moves: an irrelevance result", in economics bulletin, 2001, volume 12. On-line: http://www.accessecon.com/includes/ CountdownloadPDF.aspx? PaperID=EB-01L30001

[18] Q. Gu; J. Ji, and T. Gao, "Price decisions for new product with and without subsidy", in IEEE International Conference on Service Operations and Logistics and Informatics (SOLI), pp: 35 - 39, 2010.

[19] M. Sertel, "Regulation by Participation", in Journal of Economics, Volume 48, Issue 2, Springer, pp: 111-134, 1988.

[20] M.J. Osborne; A. Rubenstein, "A Course in Game Theory”, Chapter 6, MIT Press, pp: 89-115, 1994.

[21] R. Gibbons, "A primer in game theory", Chapter 2, HarvesterWheatsheaf, pp: 55-141, 1992. 